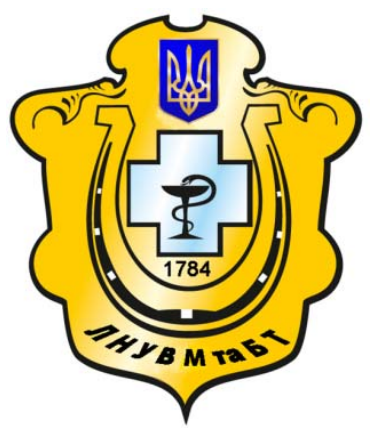

Науковий вісник Львівського національного університету ветеринарної медицини та біотехнологій імені С.3. Гжицького

Scientific Messenger of Lviv National University of Veterinary Medicine and Biotechnologies named after S.Z. Gzhytskyj

doi:10.15421/nvlvet6906

ISSN 2413-5550 print

ISSN 2518-1327 online

http://nvlvet.com.ua/

УДК 339.138 : [332.122:338.43] : [332.135:339.9]

\title{
Роль маркетингу в розвитку сільських територій прикордонного регіону: євроінтеграційний контекст
}

\author{
О.Я. Гримак, І.К. Кравців \\ grumo@i.ua

\begin{abstract}
Львівський національний університет ветеринарної медицини та біотехнологій імені С.3. Гжицького,
\end{abstract} \\ вул. Пекарська, 50, м. Львів, 79010, Украӥна
}

\begin{abstract}
Окреслено пріоритетні напрями розвитку сільських територій у руслі політки європейської інтеграції Украӥни. Доведено необхідність впровадження сучасних управлінських технологій у практику діяльності органів місиевого самоврядування сільських територіальних громад Украӥни. Першочерговий акцент зроблено на сільських територіях прикордонних регіонів України, які найбільш відчутно стикаються із сучасними викликами європейської інтеграчії намої держави. Відзначено необхідність забезпечувати першочерговий розвиток маркетингу сільських територій у прикордонних регіонах Украйни в таких ключових напрямах: інституційно-економічному, інформачійно-управлінському, сочіально-культуральному. На цій основі здійснено систематизачії основних завдань розвитку маркетингу сільських територій прикордонних регіонів України у кожній із трьох окреслених площин, відповідно до основних викликів сучасного етапу європейської інтеграчії України. Розроблено пропозичії для органів державної влади та місцевого самоврядування України, в яких першочергове значення відведене начально-освітній та інформаційно-консалтинговій компонентам з метою підвищення якості управлінськоі підготовки прачівників органів місиевого самоврядування сільських територіальних громад у прикордонних регіонах України. Показано, щзо більшості європейських урядів довелося відмовитися від надміру витратної системи прямої бюджетної підтримки сільськогосподарських товаровиробників. Замість иього було впроваджено механізм фінансових субсидій, спрямований, насамперед, на стимулювання інновачій в аграрному секторі економіки, а також на ведення екологічно безпечного сільського господарства. Крім того, суттево зросла частка витрат на розвиток інфраструктури сільських територій та фінансування програм соиіально-культурного розвитку села. Аналізуючи особливості функиіонування інституційноправового механізму реалізації спільної аграрної політики ЄС, відзначено, щяо в СС дедалі частіше організаційною платформою для здійснення заходів з розвитку сільськогосподарського виробництва стають не стільки фермерські господарства чи агрокорпорації, скільки сільські території та сільські громади загалом. Перспективою подальших наукових досліджень у руслі окресленої проблематики є виявлення резервів нарощування людського потенціалу сільських територій в умовах поглиблення європейської інтеграції України
\end{abstract}

Ключові слова: маркетинг, сільські території, європейська інтеграџія, місцеве самоврядування, прикордонний регіон.

\section{Роль маркетинга в развитии сельских территорий приграничного региона: евроинтеграционный контекст}

\author{
О.Я. Грымак, И.К. Кравцив \\ grumo@i.ua
}

\begin{abstract}
Львовский национальный университет ветеринарной медицины и биотехнологий имени С.3. Гжсиикого, ул. Пекарская, 50, г. Львов, 79010, Украина
\end{abstract}

Очерчены приоритетные направления развития сельских территорий в русле политики европейской интеграции Украины. Доказана необходимость внедрения современных управленческих технологий в практику деятельности органов местного самоуправления в сельских территориальных общинах Украины. Первоочередной акиент сделан на сельских территориях приграничных регионов Украины, которые наиболее очутимо сталкиваются с современными вызовами европейской

\section{Citation:}

Hrymak, O., Kravtsiv, I. (2016). The role of marketing in development of rural territories of the near-border region: european integration context. Scientific Messenger LNUVMBT named after S.Z. Gzhytskyj, 18, 2(69), 33-40. 
интеграчии. Отмечена необходимость обеспечивать первоочередное развитие маркетинга сельских территорий в приграничных регионах Украинь в таких ключевых направлениях: институционально-экономическом, информационноуправленческом, социально-культуральном. На этой основе была осуществлена систематизация основных задач развития маркетинга сельских территорий в приграничных регионах Украины. В частности, речь идет о каждой из трех очерченных плоскостей, в соответствии с основныли вызовами современного этапа европейской интеграции Украины. Разработаны предложения для органов государственной власти и местного самоуправления Украины, в которых первостепенное значение отведено учебно-образовательной и информачионно-консалтинговой компонентам с иелью повьшения качества управленческой подготовки кадров для органов местного самоуправления в сельских территориальных общинах, прежде всего в приграничных регионах Украиньл. Показано, что больиинству европейских правительств пришлось отказаться от избытка расходной системы прямой бюджетной поддержки сельскохозяйственных товаропроизводителей. Вместо этого был введен механизм финансовых субсидий, направленный прежде всего на стимулирование инноваций в аграрном секторе экономики, а также на ведение экологически безопасного сельского хозяйства. Кроме того, существенно возросла доля расходов на развитие инфраструктуры сельских территорий и финансирования программ соииально-культурного развития села. Анализируя особенности функционирования институцчинально-правового механизма реализации совместной аграрной политики ЕС, отмечено, что в ЕС все чаще организационной платформой для осуществления мероприятий по развитию сельскохозяйственного производства становятся не столько фермерские хозяйства или агрокорпорации, сколько сельские территории и сельские обшины в цуелом. Перспективой дальнейших научных исследований в русле обозначенной проблематики является выявление резервов наращчивания человеческого потенциала сельских территорий в условиях углубления европейской интеграции Украины.

Ключевые слова: маркетинг, сельские территории, европейская интеграчия, местное самоуправление, приграничный регион

\title{
The role of marketing in development of rural territories of the near-border region: european integration context
}

\author{
O. Hrymak, I. Kravtsiv \\ grumo@i.ua \\ Lviv National University of Veterinary Medicine and Biotechnologies named after S.Z. Gzhytskyi, \\ Pekarska Str., 50, Lviv, 79010, Ukraine
}

\begin{abstract}
The priority directions of development of rural areas in line with the policy of European integration of Ukraine have outlined. The necessity of introduction of modern managerial technologies in practice of activity of local authorities in rural communities of Ukraine was proved. Primary accent is done on rural areas of near-border regions of Ukraine, which most perceptibly are faced with modern challenges of European integration. A necessity to provide the development of rural areas marketing in the near-border regions of Ukraine was marked. Was proposed the key directions of such activity, in particular: institutional-economic, informational-managerial and socio-cultural. On this back-ground, was carried out systematization of the main tasks of rural areas marketing development in the near-border regions of Ukraine. In particular, this applies to each of the three defined planes, in accordance with the basic challenges of the present stage of European integration of Ukraine. The some proposals for state institutions and for local authorities of Ukraine have developed. In them the paramount importance is given to training and educational-consulting components to improve the quality of managerial training for local authorities in rural communities, especially in near-border regions of Ukraine. It is shown that majority of European governments had to reject too expensive system of direct budget support of agricultural producers. Instead financial subsidies mechanism was introduced primarily aimed at stimulating innovation in agricultural sector of the economy, and to conduct environmentally friendly agriculture. In addition, the share of expenditures on infrastructure and rural finance programmes for social-cultural development of the village has increased significantly. Analysing the peculiarities of the institutional and legal mechanism for implementing of the EU Common Agricultural Policy, noted that in EU more often an organisational platform for the implementation of the activities on agricultural production development are not only farmers households or agricorporations, as rural areas and rural communities in general. Perspective of the further research in direction with the outlined issues is identifying reserves for human potential of rural areas increase in terms of deepening European integration of Ukraine.
\end{abstract}

Key words: marketing, rural areas, European integration, local government, border region.

\section{Ветуп}

Протягом останніх років європейська економіка розвивається в руслі трансформації інституційних основ свого функціонування, адаптуючись до посилення міжнародної конкуренції за природні ресурси, технології, людський капітал тощо. Як наслідок, упродовж минулого десятиріччя ЄС стикнувся 3 кількома серйозними фінансово-економічними та соціально-політичними кризами, які активізували дискусії щодо фундаментальних основ організації їх спільного господарського устрою. Це потягнуло за собою впровадження інновацій у різних ланках європейської економіки, починаючи із фінансового та безпекового секторів, і закінчуючи реформуванням Спільної аграрної політики ЄС.

Зокрема, більшості європейських урядів довелося відмовитися від надміру витратної системи прямої бюджетної підтримки сільськогосподарських товаровиробників. Замість цього було впроваджено механізм фінансових субсидій, спрямований, насамперед, на стимулювання інновацій в аграрному секторі економіки, а також на ведення екологічно безпечного сільського господарства. Крім того, суттєво зросла частка витрат на розвиток інфраструктури сільських 
територій та фінансування програм соціальнокультурного розвитку села.

Дослідники Інституту регіональних досліджень НАН України вказують на наявність трьох ключових пріоритетів сільського розвитку в країнах-членах $\mathrm{CC}$, задекларованих у Стратегії «Свропа 2020», а саме: розумний розвиток (підтримка інновацій і «зелених технологій»), сталий розвиток (підвищення ефективності використання ресурсів для стимулювання базових рівнів виробництва продуктів харчування, а також скорочення викидів і розвиток біоенергетики), всеохоплюючий розвиток (реалізація місцевого потенціалу, диверсифікація сільської економіки та створення нових робочих місць, реструктуризація сільського господарства) (Borshchevskyi, 2012).

Розпочата у СС реформа Спільної аграрної політики скасувала прямий зв'язок між обсягом допомоги, яку отримують фермери, та обсягом виробленої продукції. Таким чином, виплати фермерам більше не пов'язуються безпосередньо із виробництвом конкретного продукту. Було задекларовано спрощення так званої системи норм, необхідних для отримання субсидій (cross compliance); зокрема шляхом вилучення стандартів, що прямо не стосуються відповідальності фермера чи з нею не пов'язані. Водночас, єврочиновники ініціювали впровадження низки нових вимог, спрямованих на збереження екологічних переваг тримання землі під паром чи поліпшення управління водними ресурсами. Крім того, заходи, які вживаються ЄС для забезпечення сільськогосподарської пропозиції, більше не повинні перешкоджати спроможності фермерів адекватно відповідати на ринкові сигнали. Передусім це стосується лібералізації інтервенційної політики щодо виробництва твердої пшениці, рису та свинини, кормового зерна тощо.

Разом із цим, науковці Національного інституту стратегічних досліджень, аналізуючи особливості функціонування інституційно-правового механізму реалізації спільної аграрної політики СС, відзначають, що в ЄС дедалі частіше організаційною платформою для здійснення заходів 3 розвитку сільськогосподарського виробництва стають не стільки фермерські господарства чи агрокорпорації, скільки сільські території та сільські громади загалом. При цьому фермери залишаються важливими економічними, а також соціальними та культурними суб'єктами господарської діяльності, проте дедалі більша кількість мешканців села знаходять зайнятість саме в неаграрній сфері (Borshchevskyi, 2014).

Це актуалізує необхідність дослідження сучасних тенденцій розвитку сільських територій України 3 урахуванням досвіду країн-членів СС. Передусім важливість таких наукових досліджень виявляється в контексті розвитку сільських територій прикордонних регіонів нашої держави, які межують з СС, i, відповідно, мають кращі просторові передумови для адаптації на вітчизняний грунт ефективних i перевірених часом управлінських засобів та механізмів з країнчленів СС.

На особливу увагу у цьому зв'язку заслуговує впровадження у діяльність органів місцевого самоврядування сільських територіальних громад у прико- рдонних регіонах України сучасних маркетингових технологій з метою забезпечення розвитку та диверсифікації економіки відповідних сільських територій. Саме тому пошук пріоритетних напрямів трансферту технологій регіонального маркетингу, поширених у країнах-членах $\mathrm{CC}$, та розробка пропозицій щодо адаптації їх на вітчизняний грунт у межах сільських територій прикордонних регіонів України і $є$ основною метою цієї статті.

\section{Матеріал і методи досліджень}

Дослідження проведене на матеріалах наукових публікацій українських і закордонних учених, а також з використанням статистичних даних, які знаходяться у відкритому доступі.

Основними методами наукового дослідження, які використовувалися у процесі написання цієї статті стали загальнонаукові методи аналізу та синтезу, абстрактно-логічний, системного аналізу, порівняльних оцінок тощо.

\section{Результати та їх обговорення}

Систематизуючи основні завдання маркетингу сільських територій прикордонних регіонів ЄС та сусідніх із ним держав, відповідно до нових викликів європейської інтеграції, можна запропонувати «матрицю пріоритетів», згрупованих за трьома основними напрямами: інституційно-економічним, інформаційно-управлінським та соціально-культуральним. На перетині кожної пари напрямів формуються відповідні площини розвитку маркетингу сільських територій, в межах яких відбувається удосконалення маркетингових механізмів та інструментів просування інтересів кожної з цих територій у контексті адаптації економіки прикордонного регіону до нових викликів європейської інтеграції. (рис. 1)

Наприклад, інституційно-економічний та інформаційно-управлінський напрями формують площину транскордонних комунікацій. У цій площині відбувається удосконалення систем обміну маркетинговою інформацією між сусідніми сільськими прикордонними територіями різних держав, а також модернізуються транскордонні маркетингові комунікаційні мережі, які охоплюють сільські території всього транскордонного регіону. Враховуючи системоутворюючі напрями розвитку маркетингу сільських територій у межах цієї площини (інституційно-економічний та інформаційно-управлінський), основними чинниками удосконалення маркетингових комунікацій тут виступають: розвиток транскордонних інституцій (єврорегіонів, кластерів, партнерств тощо), інституціоналізація транскордонного простору (формування спільних транскордонних стратегій регіонального розвитку, налагодження прямих економічних і ділових контактів між сільськими територіальними громадами по різні боки кордону, підписання між ними двосторонніх угод i виконавчих протоколів до них тощо), інноваційний розвиток інформаційно-комунікаційної інфраструктури у прикордонних регіонах загалом і в межах їх сільських територій, зокрема. 


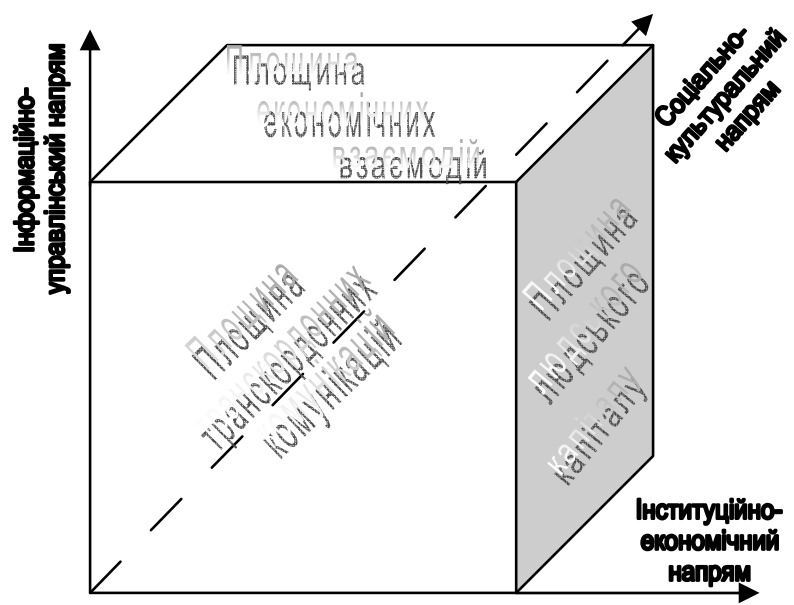

Рис. 1. Пріоритетні напрями розвитку маркетингу сільських територій прикордонного регіону в умовах нових викликів свропейської інтеграції

Складено І. Кравців

Площина економічних взаємодій, що виникає на перетині соціально-культурного та інституційноекономічного напрямів розвитку маркетингу сільських територій, забезпечує удосконалення його інструментів і механізмів функціонування на основі дії таких чинників, як розвиток прикордонної торгівлі і транскордонних ринків сільськогосподарської продукції та послуг, які надаються мешканцями сільських територій у прикордонних регіонах, реалізація спільних транскордонних інвестиційних проектів, спрямованих на удосконалення інфраструктури села, підвищення його соціально-економічного та ресурсного потенціалу, вирівнювання пропорцій економічного розвитку та соціальних стандартів життя мешканців прикордонних сільських територій по різні боки кордону.

Площина людського капіталу, пріоритетними у наповненні якої реальним змістом $є$ інформаційноуправлінський та соціально-культурний напрями розвитку маркетингу сільських територій, відображає гуманітарний контекст транскордонного співробітництва, що виявляється у підвищенні ефективності маркетингових механізмів просування інтересів мешканців сільських територій прикордонних регіонів. Ключовими чинниками іiї формування та еволюції виступають: реалізація навчально-освітніх проектів транскордонного характеру, що фінансуються зі структурних фондів СC і мають на меті підвищення якості людського та соціального капіталу прикордонних сіл, здійснення адміністративно-територіальної реформи та підвищення інституційної спроможності органів місцевого самоврядування прикордонних сільських територіальних громад, проведення спільних культурно-мистецьких заходів за участю мешканців сільських територій прикордонних регіонів сусідніх країн тощо.

Разом із цим, кожна із трьох окреслених площин чинить як прямий, так і опосередкований вплив на удосконалення маркетингових інструментів розвитку сільських територій прикордонних регіонів під впливом дії традиційних і сучасних викликів європейської інтеграції. Зокрема, враховуючи тенденції соціальноекономічного розвитку $€ \mathrm{C}$, а також характер розвитку міжнародної конкуренції та глобалізації на сучасному етапі, доцільно виокремити чотири групи викликів, які впливають на розвиток маркетингу сільських територій прикордонних регіонів у контексті поглиблення європейської інтеграції: посилення конкуренції за людські та природні ресурси, дефіцит фінансових ресурсів і пов'язані із ним проблеми наповнення бюджетів різних рівнів, загострення міграційної кризи, а також поява цілої низки нових безпекових викликів регіонального, транскордонного, континентального та глобального характеру.

Усю множинність взаємозв'язків між сучасними викликами європейської інтеграції та розвитком окремих ланок маркетингу сільських територій прикордонного регіону в межах вищеокреслених трьох площин можна відобразити у вигляді відповідної таблиці (табл. 1).

Як можна побачити, кожна із трьох площин розвитку маркетингу сільських територій прикордонних регіонів містить своє конкретне наповнення відповідно до кожного із чотирьох описаних основних викликів сучасної європейської інтеграції.

Так, у площині економічних взаємодій, у відповідь на посилення міжнародної конкуренції за людські та природні ресурси, відбувається розвиток брендингу прикордонних сільських та засобів формування їх іміджу з метою підвищення конкурентоспроможності цих територій у боротьбі за інвестиції та потенційних споживачів послуг. Крім того, розвиток брендингу та формування позитивного іміджу прикордонних сільських територій $є$ важливим засобом мотиваційного впливу на мешканців цих територій, з метою недопущення відтоку кваліфікованих кадрів за кордон. 
Таблиця 1

Вплив основних викликів європейської інтеграції на розвиток маркетингу сільських територій прикордонного регіону

\begin{tabular}{|c|c|c|c|c|}
\hline \multirow{2}{*}{$\begin{array}{c}\text { Площини роз- } \\
\text { витку маркетингу } \\
\text { сільських терито- } \\
\text { рій }\end{array}$} & \multicolumn{4}{|c|}{ Виклики європейської інтеграції } \\
\hline & $\begin{array}{c}\text { Посилення конкуре- } \\
\text { нції }\end{array}$ & Бюджетні проблеми & Міграційна криза & Безпекові виклики \\
\hline \multirow{3}{*}{ 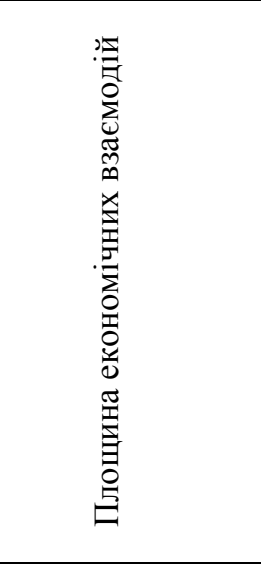 } & $\begin{array}{l}\text { Розвиток засобів } \\
\text { формування позити- } \\
\text { вного іміджу терито- } \\
\text { рії та брендингу }\end{array}$ & \multirow{2}{*}{$\begin{array}{l}\text { Удосконалення } \\
\text { маркетингових } \\
\text { інструментів фор- } \\
\text { мування цін на } \\
\text { ресурси сільської } \\
\text { території та на пос- } \\
\text { луги, що надаються } \\
\text { в їі межах }\end{array}$} & \multirow{3}{*}{$\begin{array}{l}\text { Диверсифікація та } \\
\text { підвищення функ- } \\
\text { ціональної спромо- } \\
\text { жності системи мар- } \\
\text { кетингових дослід- } \\
\text { жень з метою збіль- } \\
\text { шення обсягів залу- } \\
\text { чення прямих інозем- } \\
\text { них інвестицій у } \\
\text { розвиток прикор- } \\
\text { донної, транспортної } \\
\text { та соціальної інфра- } \\
\text { структури }\end{array}$} & $\begin{array}{l}\text { Налагодження } \\
\text { механізмів «безпе- } \\
\text { кового маркетин- } \\
\text { гу» території }\end{array}$ \\
\hline & $\begin{array}{l}\text { Формування та просу- } \\
\text { вання транскордонних } \\
\text { інвестиційних проектів }\end{array}$ & & & \multirow{2}{*}{$\begin{array}{l}\text { Створення та про- } \\
\text { сування нових «про- } \\
\text { дуктів» сільських } \\
\text { територій у сферах } \\
\text { транскордонної } \\
\text { безпеки та транс- } \\
\text { кордонних без- } \\
\text { пекових послуг }\end{array}$} \\
\hline & $\begin{array}{l}\text { Трансфер марке- } \\
\text { тингових технологій } \\
\text { просування інтересів } \\
\text { території в межах транс- } \\
\text { кордонного простору }\end{array}$ & $\begin{array}{l}\text { Еволюція інстру- } \\
\text { ментів спільного } \\
\text { просування товарів і } \\
\text { послуг бізнесу та } \\
\text { сільської території } \\
\text { загалом }\end{array}$ & & \\
\hline \multirow{3}{*}{ 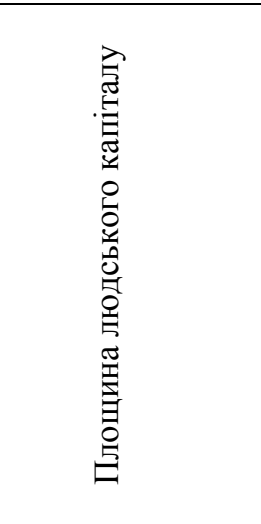 } & \multirow{2}{*}{$\begin{array}{l}\text { Залучення потенціалу } \\
\text { управлінських нави- } \\
\text { чок і знань трудових } \\
\text { мігрантів у сферу мар- } \\
\text { кетингу прикордон- } \\
\text { них сільських терито- } \\
\text { рій }\end{array}$} & \multirow{3}{*}{$\begin{array}{l}\text { Нарощування кад- } \\
\text { рового потенціалу та } \\
\text { поліпшення кадрово- } \\
\text { го забезпечення мар- } \\
\text { кетингу прикор- } \\
\text { донних сільських } \\
\text { територій завдяки } \\
\text { переходу частини } \\
\text { держслужбовців у } \\
\text { сферу консалтингу та } \\
\text { на роботу в органи } \\
\text { місцевого самовря- } \\
\text { дування }\end{array}$} & \multicolumn{2}{|c|}{$\begin{array}{l}\text { Формування системи транскордонного } \\
\text { маркетингу людського капіталу сільських } \\
\text { територій }\end{array}$} \\
\hline & & & $\begin{array}{l}\text { Поліпшення кадро- } \\
\text { вого забезпечення } \\
\text { маркетингу сільсь- } \\
\text { ких територій }\end{array}$ & \multirow{2}{*}{$\begin{array}{l}\text { Створення нових } \\
\text { маркетингових про- } \\
\text { дуктів, орієнтованих } \\
\text { на просування спі- } \\
\text { льної культурної } \\
\text { спадщини сільських } \\
\text { територій прикор- } \\
\text { донних регіонів ЄС } \\
\text { та сусідніх із ним } \\
\text { країн }\end{array}$} \\
\hline & $\begin{array}{l}\text { Інтенсифікація обмі- } \\
\text { ну знаннями в межах } \\
\text { транскордонного } \\
\text { навчально-освіт- } \\
\text { нього простору }\end{array}$ & & $\begin{array}{l}\text { Становлення } \\
\text { транскордонного } \\
\text { маркетингу соці- } \\
\text { ального капіталу } \\
\text { сільських територій }\end{array}$ & \\
\hline \multirow{3}{*}{ 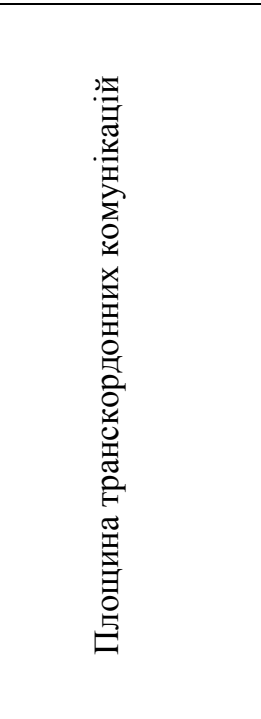 } & $\begin{array}{l}\text { Інтенсифікація інфо- } \\
\text { рмаційних потоків } \\
\text { між прикордонними } \\
\text { сільськими територі- } \\
\text { ями сусідніх держав }\end{array}$ & \multirow{2}{*}{$\begin{array}{l}\text { Розвиток системи } \\
\text { транскордонних } \\
\text { комунікацій на рівні } \\
\text { органів місцевого } \\
\text { самоврядування } \\
\text { прикордонних сіль- } \\
\text { ських територіаль- } \\
\text { них громад, євроре- } \\
\text { гіонів та бізнесу по } \\
\text { різні боки кордону }\end{array}$} & \multirow{3}{*}{$\begin{array}{l}\text { Активізація транс- } \\
\text { кордонних комуні- } \\
\text { каційних заходів за } \\
\text { сприяння СС, з ме- } \\
\text { тою об'єднання } \\
\text { зусиль органів дер- } \\
\text { жавної влади, місце- } \\
\text { вого само- } \\
\text { врядування та НУО } \\
\text { щодо вирішення } \\
\text { міграційних про- } \\
\text { блем, у т.ч. на осно- } \\
\text { ві удосконалення } \\
\text { інфраструктури та } \\
\text { інноваційного роз- } \\
\text { витку прикордон- } \\
\text { них сільських тери- } \\
\text { торій }\end{array}$} & \multirow{3}{*}{$\begin{array}{l}\text { Формування тран- } \\
\text { скордонних кому- } \\
\text { нікаційних мереж } \\
\text { із високим рівнем } \\
\text { захисту інформації, } \\
\text { підвищення на цій } \\
\text { основі якості мар- } \\
\text { кетингової інфор- } \\
\text { мації, що викорис- } \\
\text { товується для про- } \\
\text { сування інтересів } \\
\text { сільських терито- } \\
\text { рій прикордонних } \\
\text { регіонів з метою } \\
\text { залучення потен- } \\
\text { ційних іноземних } \\
\text { інвесторів }\end{array}$} \\
\hline & $\begin{array}{l}\text { Розвиток інформа- } \\
\text { ційної інфраструктури, } \\
\text { зокрема Інтернету і } \\
\text { мобільного зв’язку }\end{array}$ & & & \\
\hline & $\begin{array}{l}\text { Формування нових } \\
\text { засобів і технологій } \\
\text { просування інтересів } \\
\text { сільських територіа- } \\
\text { льних громад у ме- } \\
\text { жах транскордонних } \\
\text { регіонів }\end{array}$ & $\begin{array}{l}\text { Інтенсифікація } \\
\text { маркетингово- } \\
\text { комунікаційної } \\
\text { діяльності в межах } \\
\text { єврорегіонів, транс- } \\
\text { кордонних класте- } \\
\text { рів, інших транско- } \\
\text { рдонних інституцій }\end{array}$ & & \\
\hline
\end{tabular}

Складено І. Кравців

Наприклад, О. Павлов відзначає: «Сільські території як маркетинговий об'єкт постають не тільки як реальний географічний простір, наповнений матеріальними об'єктами та людськими істотами, а також як ментальний простір. Ментальність не тільки формує територіальну ідентифікацію, але й приймає активну участь у створенні просторових утворень. Індивід або спільнота людей, наділені певним менталітетом, перетворюють природний ландшафт на власний розсуд, керуючись при цьому системою поглядів, умонастроїв, духовних та культурних традицій, що сформувалися в процесі історичної еволюції. Паралельно, у людській свідомості в процесі перетворюючої діяльності формується та закріплюється той чи інший тип мен- 
тального простору думок, образів, почуттів, відчуттів, в якому віддзеркалюється простір реальний» (Pavlov, 2014).

У цій же площині у відповідь на посилення конкуренції відбувається підвищення якості формування та просування інвестиційних пропозицій, а також активізація трансферу ефективних маркетингових технологій від більш розвинених сільських територій до органів місцевого самоврядування менш розвинутих сільських територіальних громад у межах всього транскордонного простору. При цьому особливу увагу слід акцентувати на формуванні та просуванні транскордонних інвестиційних проектів, включаючи синергетичні механізми та створення нових маркетингових продуктів за рахунок використання транскордонного потенціалу сільських територій прикордонних регіонів.

Площина економічних взаємодій передбачає також застосування більш якісних інструментів маркетингової цінової політики з метою правильного формування прикордонними сільськими територіями цін на власні ресурси і послуги у відповідь на зменшення обсягів бюджетного та грантового фінансування в умовах викликів, породжених бюджетною кризою в ЄС. Вказана криза також стимулює поглиблення співпраці між органами місцевого самоврядування сільських територій прикордонних регіонів і підприємницькими структурами, включаючи іноземних інвесторів, 3 метою спільного використання ними маркетингових мереж та засобів просування власних економічних інтересів.

У відповідь на «міграційні» виклики сучасності у площині економічних взаємодій відбувається формування нових напрямів маркетингових досліджень щодо пошуку сільськими територіями прикордонних регіонів тих інвестиційних ресурсів, які можна залучити в розвиток виробничої та прикордонної інфраструктури 3 метою створення додаткових робочих місць та зменшення потоків трудових мігрантів у країни-члени СС.

На окрему увагу заслуговує розвиток маркетингу сільських територій прикордонних регіонів у відповідь на посилення безпекових викликів європейської інтеграції. Передусім це стосується виникнення феномену «безпекового маркетингу» території, пов'язаного з використанням маркетингових інструментів задля нівелювання таких ризиків, як екологічні (включаючи загрозу техногенних катастроф), соціальні (у тому числі поширення різних форм девіантної поведінки та породження соціальних протестних настроїв) та військово-політичні (зокрема, ризики тероризму та гібридних війн). Одним із важливих напрямів розвитку безпекового маркетингу території $\epsilon$ створення якісної системи захисту інформації, а також підвищення ефективності функціонування маркетингових комунікаційних каналів з метою активізації рекламно-пропагандистської діяльності та просування безпекових інтересів відповідних регіонів.

У цьому контексті О. Іллєнко, наприклад, відмічає, що прагнення до економічної безпеки суб'єктів зовнішньоекономічної діяльності значно підвищує роль міжнародного маркетингу як одного 3 ключових ін- струментів управління в умовах глобальної конкуренції. Це зумовлює необхідність дедалі активнішого впровадження та використання методології міжнародного маркетингу при забезпеченні міжнародної економічної безпеки в умовах глобалізації. При цьому в теоретичній та прикладній площинах виникають проблеми захисту ринкових та економічних інтересів суб'єктів міжнародної економічної діяльності, прогнозування та моніторингу загроз їх економічній безпеці, аналізу та систематизації наявного потенціалу та позиціонування вказаних суб'єктів у системі світо господарський зв'язків та міжнародному поділі праці (Illienko, 2013).

Найбільш актуальними ті завдання, що стоять перед безпековим маркетингом, сьогодні виявляються для прикордонних регіонів окремих держав, особливо тих, які знаходяться на перетині геополітичних та геоекономічних інтересів, включаючи наближеність до зовнішніх кордонів СС. Це означає, що для сільських територій прикордонних регіонів України безпековий маркетинг виступає однією з найважливіших i достатньо перспективних ланок маркетингового просування своїх економічних інтересів у середовищі глобальної конкуренції та європейської інтеграції, будучи спроможним відповідати на ключові і найгостріші виклики сучасності та нівелювати численні ризики, пов'язані з небезпекою зовнішньої експансії, зокрема економічної, у найближчій і більш віддаленій перспективі.

Важливим напрямом розвитку маркетингу сільських територій прикордонних регіонів у площині економічних взаємодій, як реакція на загострення безпекових викликів європейської інтеграції, є удосконалення товарної та цінової політики в контексті використання наявних ресурсів території. Наприклад, для збільшення обсягів залучення прямих іноземних інвестицій та диверсифікації сільської економіки у прикордонних регіонах можуть формуватися нові інвестиційні пропозиції щодо формування та просування таких «продуктів», як полігони, навчальні бази для підготовки вояків і бійців спецпідрозділів, встановлення технічних засобів обробки інформації для підрозділів органів національної безпеки, охорони кордону, протидії інформаційній експансії з-за кордону тощо.

Не менш значимою для розвитку маркетингу сільських територій прикордонних регіонів у відповідь на виклики європейської інтеграції є площина людського капіталу. В іiі межах можуть формуватися нові маркетингові продукти, пов'язані з інтенсифікацією обміну знаннями в межах транскордонного навчально-освітнього простору та залучення потенціалу управлінських навичок і знань трудових мігрантів у сферу маркетингу прикордонних сільських територій (у відповідь на виклик посилення конкуренції за людські та природні ресурси); відбуватися нарощування кадрового потенціалу та поліпшення кадрового забезпечення маркетингу прикордонних сільських територій завдяки переходу частини держслужбовців у сферу консалтингу та на роботу в органи місцевого самоврядування (у відповідь на загострення бюджетної кризи в (С); активізуватися транскордонний мар- 
кетинг людського капіталу сільських територій та створюватися нові маркетингові продукти, орієнтовані на просування спільної культурної спадщини сільських територій прикордонних регіонів ЄС та сусідніх із ним країн (у відповідь на безпекові виклики), а також поліпшуватися кадрове забезпечення маркетингу прикордонних сільських територій і підвищуватися ефективність використання маркетингових інструментів формування соціального капіталу сільських територій у транскордонному просторі (у відповідь на міграційні виклики сучасності).

У площині транскордонних комунікацій вищеперелічені виклики європейської інтеграції стимулюють розвиток маркетингу сільських територій прикордонних регіонів у таких напрямах:

- формування транскордонних комунікаційних мереж із високим рівнем захисту інформації та підвищення на цій основі якості маркетингової інформації, що використовується для просування інтересів сільських територій прикордонних регіонів 3 метою залучення потенційних іноземних інвесторів (реакція на безпекові виклики);

- активізація транскордонних комунікаційних заходів за сприяння ЄС, з метою об’єднання зусиль органів державної влади, місцевого самоврядування та неурядових організацій, зокрема наукових установ, щодо вирішення міграційних проблем, у т.ч. на основі удосконалення прикордонної інфраструктури та інноваційного розвитку прикордонних сільських територій (реакція на загострення міграційних проблем);

- розвиток системи транскордонних комунікацій на рівні органів місцевого самоврядування прикордонних сільських територіальних громад, єврорегіонів та бізнесу по різні боки кордону та інтенсифікація маркетингово-комунікаційної діяльності в межах єврорегіонів, транскордонних кластерів, а також інших транскордонних інституцій (у відповідь на нестачу фінансово-бюджетних ресурсів);

- інтенсифікація інформаційних потоків між прикордонними сільськими територіями сусідніх держав, розвиток інформаційної інфраструктури, зокрема Інтернет-комунікацій і мобільного зв'язку та формування нових засобів і технологій просування інтересів сільських територіальних громад у межах транскордонних регіонів (реакція на посилення міжнародної конкуренції за людські та природні ресурси).

Відзначаючи важливість інформаційнокомунікаційної компоненти у розвитку сільських територіальних громад прикордонних регіонів України, варто погодитись із позицією вітчизняних науковців, які вказують не те, що одним з основних пріоритетів підвищення ефективності використання соціально-економічного потенціалу розвитку сільських територій України, зокрема з огляду на перспективу реалізації Угоди про Асоціацію з ЄС, є подолання наявних у сільській економіці інституційних дисфункцій шляхом реалізації низки навчально-освітніх та інноваційно-інвестиційних програм. Це забезпечить розвиток сільської освіти, впровадження сучасних механізмів агроконсалтингу та дорадництва, активізує процеси сільськогосподарської кооперації, а також дозволить мінімізувати рівень іллегалізації сільської економіки та сприятиме подоланню песимістичних очікувань селян (Borshhevs'kyj, 2014).

Не менш важливого значення у контексті виконання маркетингом сільських територій прикордонного регіону своєї інформаційно-освітньої функції на сучасному етапі європейської інтеграції України набуває аксіологічна складова. Зокрема, М. Мельник та Ю. Злидник у цьому контексті відмічають: «Принципи аксіологічної модернізації соціально-економічного розвитку мають базуватися на засадах етичноморальної парадигми суспільних взаємовідносин; дотримання і гарантії рівності прав і свобод людини і громадянина; деактивізації процесів масового споживання в суспільстві; інкорпорування екологічних цінностей, екологізації економічного світогляду; підтримки духовно-інтелектуального розвитку, соціалізації та мотивації особистості; стимулювання соціальної відповідальності, партнерства, згуртованості та солідарності економічних суб'єктів» (Melnyk and Zlydnyk, 2015).

\section{Висновки}

Підсумовуючи все зазначене, слід наголосити на тому, що впровадження маркетингу сільських територій у практику управлінської діяльності органів місцевого самоврядування сільських територіальних громад у прикордонних регіонах України є важливим чинником підвищення ефективності функціонування їх економіки на сучасному етапі європейської інтеграції України. Ключовими напрямами адаптації маркетингових технологій з метою вирішення економічних проблем сільських територій у прикордонних регіонах нашої держави доцільно, насамперед, визнати: навчально-освітню діяльність, спрямовану на підготовку якісних кадрів для системи регіонального маркетингу, модернізацію інституційної та управлінської інфраструктури сільських територій, а також розвиток їх інформаційно-консалтингового забезпечення 3 метою активізації трансферту ефективних інструментів територіального маркетингу у практику управлінської діяльності органів місцевого самоврядування сільських територіальних громад у прикордонних регіонах України, що межують з СС.

Перспективою подальших наукових досліджень у руслі окресленої проблематики є виявлення резервів нарощування людського потенціалу сільських територій в умовах поглиблення європейської інтеграції України. Першочергового значення при цьому слід надавати вивченню досвіду країн-членів СС щодо підготовки кадрів для систем регіонального маркетингу, у тому числі з урахуванням специфіки сільських територій прикордонних регіонів Західної України.

\section{Бібліографічні посилання}

Borshhevs'kyj, V. (2014). Vplyv instytucijnyh dysfunkcij na efektyvnist' vykorystannja social'noekonomichnogo potencialu rozvytku sil's'kyh terytorij [The influence of institutional dysfunction at the effectiveness of the use of socio-economic development 
potential of rural areas]. Regional economy. 7, 149-161 (in Ukrainian).

Illienko, O. (2013). Rol' mizhnarodnogo marketyngu v globalizovanij ekonomici pry formuvanni ekonomichnoi' bezpeky [The role of international marketing in a globalized economy, in the formation of economic security]. Ternopil. Vydavnychopoligrafichnyj centr Ternopil's'kogo nacional'nogo ekonomichnogo universytetu «Ekonomichna dumka». 14(1), 80-86 (in Ukrainian).

Melnyk, M., Zlydnyk, J. (2015). Aksiologichni chynnyky modernizacii' social'no-ekonomichnogo rozvytku Ukrai'ny [Axiological factors of modernization of the socio-economic development of Ukraine]. Regional economy. 7, 125-132 (in Ukrainian).
Pavlov O. (2014). Imidzh sil's'kyh terytorij jak ob'jekt marketyngu [The image of rural areas as a marketing object]. Economics of the food industry. 4, 42-47 (in Ukrainian).

Borshchevskyi V. (2012). Rozvytok silskykh terytorii v systemi yevrointehratsiinykh priorytetiv Ukrainy [The development of rural areas in the system integration priorities of Ukraine]. Lviv (in Ukrainian).

Borshchevskyi, V. (2014). Stratehichni priorytety ta mekhanizmy innovatsiinoho rozvytku silskykh terytorii Zakhidnoho rehionu Ukrainy [The strategic priorities and mechanisms for innovative development of rural areas of the Western region of Ukraine]. Lviv (in Ukrainian).

Стаття надійшла до редакиії 5.09.2016 